Sherwin N. Agustin, MD

Celso V. Ureta, MD

Natividad A. Almazan, MD

Department of Otorhinolaryngology

Head and Neck Surgery

Veterans Memorial Medical Center
Correspondence: Dr. Celso V. Ureta Department of Otorhinolaryngology Head and Neck Surgery

Veterans Memorial Medical Center

North Avenue, Diliman, Quezon City 1104

Philippines

Phone: (632) 89276426 local 1359

Email: enthns_vmmc@yahoo.com

The authors declared that this represents original materia that is not being considered for publication or has not been published or accepted for publication elsewhere in full or in part, in print or electronic media; that the requirements for authorship have been met by all the authors, and that each author believes that the manuscript represents honest work.

Disclosures: The authors signed a disclosure that there are no financial or other (including personal) relationships, intellectual passion, political or religious beliefs, and institutional affiliations that might lead to a conflict of interest.

Presented at the Philippine Society of Otolaryngology Head and Neck Surgery Descriptive Research Contest ( $1^{\text {st }}$ Place). December 6, 2019. Palawan Ballroom, Edsa Shangri La Hotel, Mandaluyong City.

\title{
A Linguistic Validation Study on the Filipino Dizziness Handicap Inventory
}

\begin{abstract} (FDHI) questionnaire among geriatric patients with dizziness.

\section{Methods:}

$\begin{array}{ll}\text { Design: } & \text { Linguistic Validation } \\ \text { Setting: } & \text { Tertiary Government Training Hospital } \\ \text { Participants: } & \text { Twenty-five (25) patients }\end{array}$
\end{abstract}

Objective: To determine the validity and reliability of the Filipino Dizziness Handicap Inventory

Results: The dizziness handicap inventory was translated into Filipino by a Filipino language specialist and an ENT specialist who are experts in their field. The translated version was easily understood by the 25 geriatric patients with Cronbach a scores of .957 overall [M=2.16; SD = 1.93]. Sub-domain item-total correlation scores (physical $M=2.6, S D=1.90$, Cronbach $a=.860$; emotional $M=1.66, S D=1.84$, Cronbach $a=.901$; and functional $M=2.5, S D=1.97$, Cronbach $a=.902$ ) demonstrated validity of the respective subdomains.

Conclusion: The Filipino Dizziness Handicap Inventory questionnaire is an internally valid tool for assessment of dizziness among geriatric patients. External validity and reliability can be evaluated in future studies employing corroborative measures and repeated testing.

\section{Keywords: content validity; Filipino dizziness handicap inventory}

Dizziness is the ninth most common complaint that leads patients to visit their primary care physicians, ranking third among those 65 to 75 years of age and first among older patients. ${ }^{1}$ Dizziness is a subjective disorder that causes psychological, functional or social abnormalities rather than simple pathological illness. ${ }^{2}$ Dysequilibrium, unsteadiness, vertigo and lightheadedness are terms that patients may use to describe their sensations. ${ }^{1}$ The common causes of vertigo may manifest differently in the elderly, with a more confusing constellation of symptoms, as patients tend to report less rotatory vertigo and more non-specific dizziness and instability. ${ }^{3}$ Underlying this phenomenon is the progressive multimodal impairment of balance, including loss of vestibular and proprioceptive functions and impairment of central integration of these and other sensory inputs associated with aging. ${ }^{3}$ In addition, skeletal muscle strength and mass are also reduced with aging, thereby increasing the risk of fall-related injuries in elderly 
ORIGINAL ARTICLES

Philippine Journal Of Otolaryngology-Head And Neck Surgery

Vol. 35 No. 2 July - DeCEMBER 2020

PJOHES

patients. ${ }^{3}$ These factors contribute to multifactorial causes of dizziness among the elderly which poses great concern, being at heightened risk for other complications brought about by their dizziness.

The Dizziness Handicap Inventory (DHI) is a questionnaire used to assess the impact of dizziness on quality of life. ${ }^{4}$ The self-report questionnaire was originally designed to quantify the handicapping effect of dizziness imposed by vestibular system disease, but it has also been used for persons with dizziness of other origins ${ }^{5}$ such as autonomic dysfunction as a result of diabetes or cardiovascular disease and even the effects of polypharmacy in the elderly with several comorbidties. ${ }^{6}$ The 25 -item questionnaire is divided in 3 sub-domains of self-perceived handicap and comprises physical, functional and emotional questions. ${ }^{4}$ It has been translated into different languages such as German, Brazilian, ${ }^{8}$ Persian ${ }^{9}$ and Italian. ${ }^{10}$

To the best of our knowledge, there is no validation study of the $\mathrm{DH}$ available in our local setting. Hence, this study aims to establish the validity and reliability of the Filipino Dizziness Handicap Index (FDHI) among a sample of geriatric patients with dizziness.

\section{METHODS}

This two-phase validation study was conducted at the Veterans Memorial Medical Center (VMMC) with Institutional Review Board approval (VMMC-2017-035). Consent for translation was obtained from the original author of the Dizziness Handicap Inventory (DHI). ${ }^{4}$

The first phase involved joint translation of the DHI into Filipino by two persons, a Filipino language professor and an Ear, Nose and Throat (ENT) specialist fluent in English and Filipino. The resulting draft FDHI was back - translated into English by another physician. Content validity of the translated FDHI was assessed by these experts to ensure that the contents of the questionnaire were appropriate and opine that it could produce reliable results. Meetings were conducted to discuss the results of the translation, and then the first version of FDHI was produced. (Figure 1)

The second phase was validation of the FDHI. The validity of the questionnaire was determined through pretesting among 25 Filipino geriatric patients. Twenty-five (25) participants aged 65 years old and above who were consulting for dizziness were serially recruited by the Ear, Nose, Throat - Head and Neck Surgery (ENT-HNS) Resident Doctors from the out-patient department (OPD) clinic and emergency ward of the VMMC Department of Otorhinolaryngology - Head and Neck Surgery from October 2017 - May 2018. Prospective participants had to be able to read, write, understand and converse in Filipino. Excluded were patients with dementia, Alzheimer's disease and other neurological disorders. Informed consent was obtained from all participants.

\section{Filipino Dizziness Handicap Inventory Pagsukat sa Antas ng Pagiging Mahiluhin}

\begin{tabular}{|c|c|c|c|}
\hline & Nakadaragdag ba sa iyong pagiging mahiluhin ang pagtingin sa itaas? & $\begin{aligned} \rho \\
\rho\end{aligned}$ & $\begin{array}{l}\text { OO } \\
\text { Minsan } \\
\text { Hindi }\end{array}$ \\
\hline E2. & Nakadarama ka ba ng pagkadismaya dahil sa iyong pagiging mahiluhin? & $\stackrel{9}{\rho}$ & $\begin{array}{l}\text { OO } \\
\text { Minsan } \\
\text { Hindi }\end{array}$ \\
\hline F3. & $\begin{array}{l}\text { Nalilimitahan ba ng iyong pagiging mahiluhin ang pagnanais mong maglakbay } \\
\text { para sa negosyo o libangan? }\end{array}$ & $\stackrel{\rho}{\rho}$ & $\begin{array}{l}\text { OO } \\
\text { Minsan } \\
\text { Hindi }\end{array}$ \\
\hline P4. & $\begin{array}{l}\text { Nakadaragdag ba sa iyong pakamahiluhin ang paglalakad sa pasilyo ng mga } \\
\text { pamilihan? }\end{array}$ & $\stackrel{\rho}{\circ}$ & $\begin{array}{l}\text { OO } \\
\text { Minsan } \\
\text { Hindi }\end{array}$ \\
\hline F5. & $\begin{array}{l}\text { Nagbubunga ba ng kahirapan sa pagbangon at paghiga sa kama ang iyong } \\
\text { pagiging mahiluhin? }\end{array}$ & $\begin{array}{r}\rho \\
\rho \\
\end{array}$ & $\begin{array}{l}\text { OO } \\
\text { Minsan } \\
\text { Hindi }\end{array}$ \\
\hline F6. & $\begin{array}{l}\text { Nalilimitahan ba ng iyong pagiging mahiluhin ang pagnanais mong lumahok } \\
\text { sa iba't ibang gawain gaya ng pagkain sa labas, panonood ng sine, pagsasayaw } \\
\text { at/o pagdalo sa mga pagtitipon? }\end{array}$ & 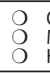 & $\begin{array}{l}\text { OO } \\
\text { Minsan } \\
\text { Hindi }\end{array}$ \\
\hline F7. & $\begin{array}{l}\text { Nakararanas ka ba ng kahirapan sa pagbabasa dahil sa iyong pagiging } \\
\text { mahiluhin? }\end{array}$ & $\stackrel{\rho}{\circ}$ & $\begin{array}{l}\text { OO } \\
\text { Minsan } \\
\text { Hindi }\end{array}$ \\
\hline P8. & $\begin{array}{l}\text { Napalaalala ba ang iyong iyong pagiging mahiluhin ng pagsasagawa ng } \\
\text { mabibigat na mgaa gawain gaya ng palahok sa iba't ibang isports, pagasaayaw at } \\
\text { mga gawaing-bahay (tulad ng pagwawalis at paghuhugas ng plato)? }\end{array}$ & $\stackrel{2}{\circ}$ & $\begin{array}{l}\text { OO } \\
\text { Minsan } \\
\text { Hindi }\end{array}$ \\
\hline E9. & $\begin{array}{l}\text { Pinangangambahan mo bang lumabas sa bahay nang walang kasama dahil sa } \\
\text { iyong pagiging mahiluhin? }\end{array}$ & $\stackrel{9}{\circ}$ & $\begin{array}{l}\text { OO } \\
\text { Minsan } \\
\text { Hindi }\end{array}$ \\
\hline E10. & $\begin{array}{l}\text { Naging dahilan ba ng iyong pagkapahiya sa harap ng maraming tao ang iyong } \\
\text { pagiging mahiluhin? }\end{array}$ & $\rho_{0}$ & $\begin{array}{l}\text { OO } \\
\text { Minsan } \\
\text { Hindi }\end{array}$ \\
\hline P11. & $\begin{array}{l}\text { Nakadaragdag ba sa iyong pagiging mahiluhin ang mabilis na paggalaw ng } \\
\text { iyong ulo? }\end{array}$ & $\stackrel{9}{\circ}$ & $\begin{array}{l}\text { OO } \\
\text { Minsan } \\
\text { Hindi }\end{array}$ \\
\hline F12. & Umiiwas ka ba sa mga matataas na lugar dahil sa iyong pagiging mahiluhin? & $\rho_{0}$ & $\begin{array}{l}\text { OO } \\
\text { Minsan } \\
\text { Hindi }\end{array}$ \\
\hline P13. & Sa pagbuwelta mo ba sa kama ay nadaragdagan ang iyong pagiging mahiluhin? & $\rho_{9}^{\circ}$ & $\begin{array}{l}\text { OO } \\
\text { Minsan } \\
\text { Hindi }\end{array}$ \\
\hline F14. & $\begin{array}{l}\text { Nahihirapan ka bang isagawa ang mas mabibigat at nakapapagod na mga } \\
\text { gawaing bahay (gaya ng paglilinis sa bakuran) dahil sa iyong pagiging } \\
\text { mahiluhin? }\end{array}$ & $\begin{aligned} \rho \\
\rho\end{aligned}$ & $\begin{array}{l}\text { OO } \\
\text { Minsan } \\
\text { Hindi }\end{array}$ \\
\hline E15. & $\begin{array}{l}\text { Pinangangambahan mo bang isipin ng iba na ika'y lasing sa alak dahil sa iyong } \\
\text { pagiging mahiluhin? }\end{array}$ & $\begin{array}{ll}\rho \\
\rho \\
O\end{array}$ & $\begin{array}{l}\text { OO } \\
\text { Minsan } \\
\text { Hindi }\end{array}$ \\
\hline F16. & Nahihirapan ka bang lumakad nang mag-isa dahil sa iyong pagiging mahiluhin? & 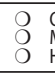 & $\begin{array}{l}\text { OO } \\
\text { Minsan } \\
\text { Hindi }\end{array}$ \\
\hline P17. & $\begin{array}{l}\text { Nakadaragdag ba sa iyong pagiging mahiluhin ang paglalakad nang pababa sa } \\
\text { mga bangketa? }\end{array}$ & 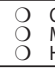 & $\begin{array}{l}\text { OO } \\
\text { Minsan } \\
\text { Hindi }\end{array}$ \\
\hline E18. & $\begin{array}{l}\text { Nahihirapan ka bang magkaroon ng sapat na konsentrasyon dahil sa iyong } \\
\text { pagiging mahiluhin? }\end{array}$ & 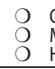 & $\begin{array}{l}\text { OO } \\
\text { Minsan } \\
\text { Hindi }\end{array}$ \\
\hline F19. & $\begin{array}{l}\text { Nahihirapan ka bang maglakad sa paligid ng inyong tahanan kapag madilim } \\
\text { dahil sa iyong pagiging mahiluhin? }\end{array}$ & 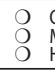 & $\begin{array}{l}\text { OO } \\
\text { Minsan } \\
\text { Hindi }\end{array}$ \\
\hline E20. & $\begin{array}{l}\text { Natatakot ka bang manatili nang mag-isa sa inyong tahanan dahil sa iyong } \\
\text { pagiging mahiluhin? }\end{array}$ & $\begin{array}{ll} & \\
\circ & 1 \\
\circ & 1 \\
\end{array}$ & $\begin{array}{l}\text { OO } \\
\text { Minsan } \\
\text { Hindi }\end{array}$ \\
\hline E21. & $\begin{array}{l}\text { Nakadarama ka ba ng kakulangan sa iyong mga kapasidad dahil sa iyong } \\
\text { pagiging mahiluhin? }\end{array}$ & $\begin{array}{l}\circ \\
\circ\end{array}$ & $\begin{array}{l}\text { OO } \\
\text { Minsan } \\
\text { Hindi }\end{array}$ \\
\hline E22. & $\begin{array}{l}\text { Naaapektuhan ba ng iyong pagiging mahiluhin ang iyong relasyon sa pamilya at } \\
\text { mga kaibigan? }\end{array}$ & $\begin{array}{ll}9 & 1 \\
9 & 1 \\
& 1\end{array}$ & $\begin{array}{l}\text { OO } \\
\text { Minsan } \\
\text { Hindi }\end{array}$ \\
\hline E23. & Nakadarama ka ba ng pagkalumbay dahil sa iyong pagiging mahiluhin? & $\begin{array}{ll}\circ & \\
O & 1 \\
O & 1 \\
\end{array}$ & $\begin{array}{l}\text { OO } \\
\text { Minsan } \\
\text { Hindi }\end{array}$ \\
\hline F24. & $\begin{array}{l}\text { Nakasasagabal ba ang iyong pagiging mahiluhin sa iyong trabaho at mga } \\
\text { responsibilidad sa tahanan? }\end{array}$ & $\begin{array}{ll} & \\
9 & 1 \\
\circ & 1 \\
& 1\end{array}$ & $\begin{array}{l}\text { OO } \\
\text { Minsan } \\
\text { Hindi }\end{array}$ \\
\hline P25. & Nakadaragdag ba sa iyong pagiging mahiluhin ang pagliyad o pagyuko? & $\begin{array}{ll} \\
\end{array}$ & $\begin{array}{l}\text { OO } \\
\text { Minsan } \\
\text { Hindi }\end{array}$ \\
\hline \multicolumn{4}{|c|}{ DHI Tagubilin sa Pagmamarka } \\
\hline \multicolumn{4}{|c|}{$\begin{array}{l}\text { Ang pasyente ay sumagot ng mga katanungan ukol sa pagkahilo o problema sa kawalan ng balanse, partikular } \\
\text { na isinasaalang-alang ang kanilang kalagayan sa panahon ng nakaraang buwan. Ang mga katanungan ay } \\
\text { dinisenyo upang isama ang functional (F), pisikal (P), at emosyonal na (E) epekto sa kapansanan. }\end{array}$} \\
\hline \multicolumn{4}{|c|}{ Sa bawat item, ang mga sumusunod na mga marka ay maaaring italaga: $\mathrm{Hindi}=0$ Kung minsan $=20 \mathrm{o}=4$} \\
\hline \multicolumn{4}{|c|}{ Mga Marka: } \\
\hline \multicolumn{4}{|c|}{$\begin{array}{l}\text { Scores mas malaki kaysa sa } 10 \text { puntos ay dapat na tinutukoy sa balanse espesyalista para sa karagdagang } \\
\text { pagsusuri. }\end{array}$} \\
\hline \multicolumn{4}{|c|}{ 0-34 Puntos (banayad na kapansanan) } \\
\hline \multicolumn{4}{|c|}{ 36-52 Puntos (katamtamang kapansanan) 54+Puntos (malubhang kapansanan) } \\
\hline
\end{tabular}

Figure 1. The Filipino Dizziness Handicap Inventory 
All eligible patients were asked to accomplish a demographic questionnaire which included basic information such as: name, age, gender, race, marital status, education, and underlying medical condition. Technical and medical terms were completed by the interviewing resident from patient medical records.

After accomplishing the general information sheet and history taking, each of the 25 selected participants were administered the 25-item FDHI, with a total score ranging from 0-100 points by summing ordinal scale responses and higher scores indicating more severe handicap. The questionnaires were answered by each patient in the presence of their companion or caregiver and a resident physician-incharge in case clarifications were needed. The respondents were given enough time to answer each of the questions and completeness of the data were ensured by the resident-in-charge and finally submitted to the investigator on the same day.

The responses were encoded and tallied using Microsoft Excel for Mac 2011 version 14.0 (Microsoft Corp., Redmond WA, USA). Nominal data frequencies and percentages were computed and mean \pm SD were generated for numerical data. Cronbach alpha was used for estimation of internal consistency. Statistical analyses were performed using the Statistical Package for Social Sciences (SPSS) Statistics version 10 (IBM Corp., Armonk, NY, USA).

\section{RESULTS}

A total of 25 participants with ages ranging from 65 to 75 years old (mean age 70 years old) completed the study. The majority $(18 ; 72 \%)$ were male, married $(23 ; 92 \%)$, college graduates $(19 ; 76 \%)$, and had co-morbidities (20; $80 \%)$. All participants were able to understand and answer all the items in the questionnaire.

For the functional subdomain of the Filipino DHI, majority of the respondents claimed to have difficulty in performing basic activities of daily living like performing household chores $(15 ; 60 \%)$, and also difficulty engaging in social activities $(14 ; 56 \%)$. For the emotional subdomain, most reported being depressed $(20 ; 80 \%)$ and feeling frustrated $(18 ; 72 \%)$ because of their dizziness. For the physical subdomain, majority answered that quick head movements increase their dizziness problems $(21 ; 84 \%)$.

Cronbach alpha for internal consistency showed the seven items under the physical sub-domain were reliable (Mean $=2.60, S D=1.90$, Cronbach $a=.860$ ). Item analysis showed good item-total correlation, indicating psychometrically-sound items. The nine items under the emotional sub-domain were likewise shown to be reliable (Mean = $1.66, \mathrm{SD}=1.84$, Cronbach $a=.901$ ). Item analysis showed also good item-total correlation, indicating psychometrically-sound items. Finally, the nine items under the functional sub-domain were also shown to be reliable (Mean $=2.50, S D=1.97$, Cronbach $a=.902$ ), with item analysis showing good item-total correlation, indicating psychometricallysound items. Overall, the 25 -item FDHI was internally valid (Mean = 2.16, $\mathrm{SD}=1.93$, Cronbach $a=.957$ )

\section{DISCUSSION}

This study established the Filipino Dizziness Handicap Inventory questionnaire as an internally valid tool for assessment of dizziness among geriatric patients. However, external validity and reliability were not established in this study.

The ability to maintain posture and orientation is one of the most indispensable conditions in daily life and is regulated by vestibular function, somatic sensation and vision. ${ }^{2}$ A problem with any one of these causes imbalance, which affects everyday life and can disable patients by causing fear, depression or anxiety. ${ }^{2}$

The Dizziness Handicap Inventory (DHI) is the first self-assessment inventory to evaluate the degree of disability in everyday life associated with any cause of dizziness on patients suffering from dizziness, developed in 1990 by Jacobson and Newman. ${ }^{4}$ Each item for the questionnaire is divided into 3 subdomains: functional, emotional, and physical area, comprised of 25 questions, and with a total of 100 points. The degree of disability is quantified based on total scores of each item. ${ }^{4}$ Among these, items concerning functional aspects are about occupation or movements related to leisure activity; items on emotional aspects are about anxiety and frustration associated with the occurrence of dizziness; and those on physical aspects cover basic physical movements often experienced in daily life. ${ }^{2}$ Validity of items were verified and reliability was shown to be high (Cronbach alpha 0.95 ) and the reliability of the questionnaire can be sustained when the test is translated into different languages. ${ }^{2}$

In terms of functional aspects, the majority of our Filipino DHI respondents reported having difficulty in performing activities of daily living (such as basic household chores) and engaging in social activities. While respondents in the Brazilian DHI study also reported interference of dizziness with such functional aspects as the capacity to perform domestic, social and leisure activities, there was a focus on independence for doing tasks such as walking without help and walking at home in the dark. ${ }^{8}$ The Persian DHI translation study also reported that participants responded having difficulty getting into and out of bed as part of their daily activities. ${ }^{9}$ On the other hand, for the Italian DHI study, the functional aspects were those most affected together with increasing age of the patients, which was probably due to the effects of aging on the vestibular system, which may enhance the functional limitations in these patients. ${ }^{10}$ 


\section{ORIGINAL ARTICLES}

In terms of emotional aspects, most respondents of our Filipino DHI study reported depression, anxiety and feelings of frustration brought about by the handicapping effects of dizziness. The Brazilian DHI study found that emotional effects created possible harm on the quality of life of affected individuals, generating frustration, fear of going out without company, or staying home alone, shame of its clinical manifestations, worries about self-image, concentration disorder, incapacity sensation, familiar or relationship alteration and depression. ${ }^{8}$ The Persian DHI study on the other hand showed that their results for the emotional subdomain had the least positive response among patients who answered the following: afraid to leave home without accompany, afraid to stay at home alone and afraid that people may think that they are intoxicated. ${ }^{9}$ While the emotional aspects evaluated by the Italian $\mathrm{DH}$ study were also abnormal in the patients studied, these aspects investigated the possible harm caused by the dizziness on the quality of life, generating frustration, fear of going outside without company or staying home alone, shame regarding the clinical manifestations, worries about concentration disorders, a sensation of incapacity, changes in family or social relationships and depression. ${ }^{10}$

Under physical aspects, most respondents of the Filipino $\mathrm{DH}$ reported that quick head movements, bending over, and walking down on sidewalks increase their dizziness problems. The Brazilian DHI study similarly found that the manifestation of dizziness in certain positions or head movements is very common and may provoke or worsen the dizziness. ${ }^{8}$ For the Persian DHI study, most also answered that quick head movements increase their dizziness (74\%), followed by bending over (72\%) and looking up (63\%) aggravates their dizziness. ${ }^{9}$ On the other hand, the physical aspects investigated by the Italian DHI study presented the highest scores, wherein the performance of physical functions such as the relationship between the manifestation and/or the severity of the dizziness and the eye and body movements, and the manifestation of dizziness in specific positions or following head movements, were significantly more affected compared to the other aspects evaluated by the $\mathrm{DHI} .{ }^{10}$

The translated FDHI questionnaire yielded a Cronbach a score of 0.957 comparable to the original $\mathrm{DHI}$ study score of $0.95^{4}$ the $\mathrm{DHI}$ German score of $0.90^{7}$ and the DHI-Italian score of $0.92 .{ }^{10}$ The process of translation of the DHI to its Filipino version was unproblematic and its internal consistency was investigated in a limited and controlled study population. It is a valid and internally consistent questionnaire and can be used as a baseline tool for future studies.

There are several limitations to our study. First and foremost, the FDHI produced after translation and back translation relied on consensus by an expert panel. While linguistic translation may have been achieved, this may not have been able to account for difference in cultural context. Time constraints limited this study to establishing content validity and internal consistency of the Filipino Dizziness Handicap Inventory only. It can still be further evaluated for face validity (for cultural adaptation) and test-retest reliability (for external reliability). Second, we had a small sample of participants sourced from an already dizzy geriatric population. Discrimination between dizzy and non-dizzy persons (as well as ability to distinguish between degrees or severity of dizziness), or assessment of dizziness in other age groups, cannot be established. Future research that includes both dizzy and non-dizzy individuals (either as a case-control study or a randomized trial) as well as other age groups may better establish the validity of the FDHI. Third, we only administered the test once at a single point in time to each participant. Establishing test - retest reliability over time, perhaps in comparison to other measures of dizziness (including corroboration with objective balance tests) would be an important step.

In conclusion, this study may have established the Filipino Dizziness Handicap Inventory questionnaire as an internally valid tool for assessment of dizziness among geriatric patients. However, external validity and reliability need to be evaluated in future studies with expanded research designs employing corroborative measures and repeated testing.

\section{REFERENCES}

1. Hullar TE, Zee DS, Minor LB. Evaluation of the patient with dizziness. In: Flint PW, Haughey BH, Lund VJ, Niparko JK, Richardson MA, Robbins K (editors). Cummings Otolaryngology Head and Neck Surgery $6^{\text {th }}$ ed. Mosby Elsevier, Philadelphia, PA: Saunders. 2015. pp.2525-2547.

2. Han GC, Kim MJ, Kim KS, Joo YH, Park SY. The dizziness handicap inventory and its relationship with vestibular diseases. J Int Adv Otol. 2012 Jan; 8(1): 69-77.

3. Fernandez L, Breinbauer HA, Delano PH. Vertigo and dizziness in the elderly. Front Neurol. 2015 Jun 26; 6:144. DOI:10.3389/fneur.2015.00144; PubMed PMID: 26167157 PubMed Central PMCID: PMC4481149.

4. Jacobson GP, Newman CW. The development of the Dizziness Handicap Inventory. Arch OtolaryngolHeadNeckSurg.1990Apr;116(4):424-7.DOI:10.1001/archotol.1990.01870040046011 PubMed PMID: 2317323.

5. Tamber AL, Wilhelmsen KT, Strand LI. Measurement properties of the Dizziness Handicap Inventory by Cross-sectional and Longitudinal designs. Health Qual Life Outcomes. 2009 Dec 21; 7:101. DOI: 10.1186/1477-7525-7-101; PubMed PMID: 20025754; PubMed Central PMCID: PMC2804706.

6. Lee ATH, Diagnosing the Cause of Vertigo: A Practical Approach. Hong Kong Med J. 2012 Aug; 18:327-32.

7. Kurre A, van Gool CJ, Bastiaenen CH, Gloor-Juzi T, Straumann D, de Bruin ED. Translation, crosscultural adaptation and reliability of the German version of the dizziness handicap inventory. Otol Neurotol. 2009 Apr;30(3):359-67. DOI: 10.1097/MAO.0b013e3181977e09. PubMed PMID: 19225437.

8. De Castro AS, Gazzola JM, Natour J, Ganança FF. Brazilian version of the dizziness handicap inventory. Pró-Fono. 2007 Jan-Apr; 19(1):97-104. DOI: 10.1590/s0104-56872007000100011; PubMed PMID: 17461352.

9. Jafarzadeh S, Bahrami E, Pourbakht A, Jalaie S, Daneshi A. Validity and reliability of the Persian version of the dizziness handicap inventory. J Res Med Sci. 2014 Aug;19(8):769-75. PubMed PMID: 25422664; PubMed Central PMCID: PMC4235099.

10. Nola G, Mostardini C, Salvi C, Ercolani AP, Ralli G. Validity of Italian adaptation of the Dizziness Handicap Inventory $(\mathrm{DHI})$ and evaluation of the quality of life in patients with acute dizziness. Acta Otorhinolaryngol Ital. 2010 Aug;30(4):190. PubMed PMID: 21253284; PubMed Centra PMCID: PMC3008147. 